disa mancinus Doubleday*, Erebia discoidalis discoidalis (Kirby), Oeneis uhleri varuna Edwards*, Oeneis macounii (Edwards), Oeneis jutta ascerta Masters \& Sorensen*.

\section{NYMPHALIDAE:}

Limenitis arthemis arthemis (Drury), Limenitis archippus archippus (Cramer), Vanessa atalanta rubria (Fruhstorfer), Cynthia virginiensis (Drury), Cynthia cardui (Linnaeus), Precis coenia coenia (Hubner)*, Nymphalis $j$-album j-album (Boisduval \& LeConte), Nymphalis antiopa antiopa (Linnaeus), Nymphalis milberti milberti (Godart), Polygonia interrogationis (Fabricius)*, Polygonia satyrus neomarsyas dos Passos, Polygonia progne (Cramer), Phyciodes tharos tharos (Drury), Phyciodes batesii (Reakirt), Chlosyne nycteis Doubleday ssp., Chlosyne harrisii (Scudder) ssp.*, Chlosyne hanhami (Fletcher)*, Boloria selene atrocostalis (Huard), Boloria bellona nr. toddi (Holland), Boloria titania grandis (Barnes \& McDunnough), Boloria frigga (Thunberg) ssp.*, Speyeria atlantis atlantis (Edwards), Speyeria atlantis nr. diennisi dos Passos \& Grey, Speyeria cybele cybele (Fabricius), Speyeria aphrodite (Fab. ricius) ssp., Euptoieta claudia claudia (Cramer).

\section{LYCAENIDAE :}

Incisalia augustinus augustinus (Westwood), Incisalia henrici henrici (Grote \& Robinson), Incisalia polios Cook \& Watson, Incisalia eryphon (Boisduval) ssp.*, Incisalia niphon clarki Freeman, Harkenclenus titus titus (Fabricius), Satyrium acadica (Edwards), ssp.*, Satyrium liparops fletcheri (Michener
\& dos Passos, Feniseca tarquinius tarquinius (Fabricius)*, Lycaena thoe Guerin-Meneville*, Lycaena xanthoidies dione Scudder, Lycaena helloides (Boisduval)*, Lycaena dorcas Kirby ssp., Lycaena epixanthe (Boisduval \& LeConte) ssp., Plebejus saepiolus saepiolus (Boisduval), Everes comyntas comyntas (Godart), Everes amyntula albrighti Clench, Glaucopsyche lygdamus couperi Grote, Celastrina argiolus argentata Fletcher.

I am indebted to C. S. Quelch of Transcona, Manitoba, who introduced me to collecting at Sandilands on my first collecting trip to Manitoba in 1966. With Mr. Quelch's guidance I located a rich colony of Oeneis macounii at Sandilands and was so intrigued by their habitat and habits that I launched my studies on the butterflies of Manitoba as well as a series of studies dealing with bionomics of Oeneis.

Good collecting can be found at Sandilands all summer. By the end of May, four species of Incisalia are fairly abundant along with Euchloe ausonides, Erebia discoidalis and Glaucopsyche lygdamus; by mid-June Oeneis macounii, Limenitis arthemis and Papilio glaucus are out in numbers; early July brings out Colias interior, Phyciodes batesii, and the Speyeria species; and August provides the Nymphalis and Polygonia species, Boloria titania, and Satyrium liparops.

\section{LITERATURE CITED}

Masters, J. H., 1972. The butterflies of Manitoba's Provincial Parks II: Grand Beach Provincial Park and Belair Forest Preserve. Blue Jay, $30: 161-166$.

\title{
EPIPHYTIC ALGAE ISOLATED FROM MOSS
}

\section{by D. R. Cullimore and A. E. McCann, University, Regina}

In the prairie region, mosses are commonly found growing on river and creek banks and also on the open prairie. As a part of the I.B.P. project at Matador, Saskatchewan, attempts were made to evaluate the role of these mosses in the ecological balance of native grassland. Paul, Campbell,
Hedlin and Lees (1972) reported that the leaves of one specific moss, Ceratodon purpureus had a high nitrogen fixing capacity of 0.02 to 1 microgram of nitrogen per hour and that fixation was light and moisture dependent. Samples of moss from Matador and similar samples from Saskatoon pos- 
sessed this property. In this study, the moss samples were examined for the presence of any algae which could have been responsible for this fixation of nitrogen.

\section{Method}

0.4 gram of moss samples were weighed and suspended in $3.6 \mathrm{ml}$. of a nutrient solution which contained all of the elements for algal growth except nitrogen. The medium was developed by Cullimore and McCann (1972A) for the isolation and enumeration of the blue-green algae ( $C y$ anophyceae) in soil. The moss was now shaken in suspension to disperse any algal cells attached to the plant. Serial dilutions of this suspension were made into the same nutrient medium using $0.4 \mathrm{ml}$. transfers into $3.6 \mathrm{ml}$. of media by the aseptic techniques described by Sirockin and Cullimore (1969). This technique diluted out the original suspension until all algae would be eliminated. All of the levels of dilution were now left in white fluorescent light at $20^{\circ} \mathrm{C}$ to allow growth of any algae present. After twelve weeks, each dilution level was examined for the types of algae present, and their numbers were calculated. This was done by presuming that the number of algae present was equivalent to the greatest dilution at

Table 1. Algal Population on Ceratodon purpureus (cells/gramwet weight).

\begin{tabular}{lccc}
\hline Genus & $\begin{array}{c}\text { Potential } \\
\text { Nitrogen } \\
\text { Fixers }\end{array}$ & $\begin{array}{c}\text { Saskatoon } \\
\text { Sample }\end{array}$ & $\begin{array}{c}\text { Matador } \\
\text { Sample }\end{array}$ \\
\hline Nostoc & + & $100,000+$ & $1,000+$ \\
Lyngbya & - & $10,000+$ & 0 \\
Oscillatoria & - & $1,000+$ & 0 \\
Chlorella & - & $100+$ & 0 \\
Pinnularia & - & 100 & 0 \\
Spongiochloris & - & $10+$ & 10 \\
Calothrix & + & $100+$ & 0 \\
Anabaicna & + & 0 & $1,000+$ \\
Mesotaenium & - & 0 & 10 \\
Diatoms & - & 0 & $10+$ \\
\hline
\end{tabular}

which the algae appeared. This technique is discussed in detail by Cullimore and McCann (1972B).

\section{Results}

Nine genera of algae were recorded on the moss samples and their population per gram is recorded as Table 1. Only one genus, Nostoc, was found to be present in significant numbers on both moss samples and it has been shown to fix nitrogen in large amounts. Other nitrogen fixing blue-green algae were also found on the moss samples. The sample from Saskatoon contained a few filaments of Calothrix, whilst the sample from Matador was rich in Anabaena. Since mosses have never been reported to be capable of fixing atmospheric nitrogen, it would appear that some form of symbolic relationship may exist between these algae (principally Nostoc) and the moss plant. In this relationship the algae may fix sufficient nitrogen to supply the moss with at least a part of its nitrogen requirements, and in return the moss would provide nutrients, ivater and protection for the algae. The high rates at which atmospheric nitrogen is fixed by the leaves in light would imply that the nitrogen fixed this way could contribute significantly to the nitrogen balance in the unique ecosystem of the native prairie grasslands.

\section{Acknowledgments}

The authors wish to thank Dr. E. A. Paul of the Soil Science Dept. University of Saskatchewan, for provision of samples and the I.B.P. program for sponsoring this project.

\section{LITERATURE CITED}

Cullimore, D. R. and A. E. McCann. 1972A. Soil Algae. Matador Project 5th Ann. Report 50-51, 203.

Cullimore, D. R. and A. E. McCann. $1972 B$. Seasonal Fluctuations in the Soil Algae. submitted manuscript.

Paul, E. A., N. E. R. Campbell, E. A. Hedlin and H. Lees. 1972. Nitrogen fixation in Soils. Matador Project 5th Ann. Report 8.

Sirockin, G.. and S. Cullimore. 1969. Practical Microbiology. 1st ed. McGraw-Hill 99-101. 